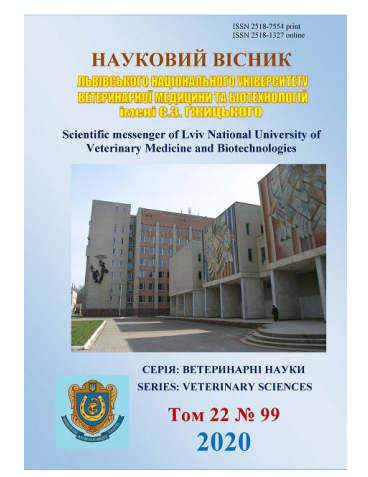

\author{
Науковий вісник Дьвівського національного університету \\ ветеринарної медицини та біотехнодогій імені С.3. Гжицыкого. \\ Серія: Ветеринарні науки \\ Scientific Messenger of Lviv National University \\ of Veterinary Medicine and Biotechnologies. \\ Series: Veterinary sciences
}

\title{
Clinical signs in dogs attributed to Yersinia enterocolitica antigen 0:9
}

\author{
I. Zon, G. Zon, L. Ivanovskaya \\ Sumy National Agrarian University, Sumy, Ukraine
}

Article info

Received 14.09.2020 Received in revised form 15.10.2020

Accepted 16.10.2020

Sumy National Agrarian University, G. Kondratieva Street, 160, Sumy, 40021, Ukraine.

Tel: $+38-05-03-076-090$

$+38-09-92-545-215$,

+38-09-96-833-414

E-mail: zonillya@hotmail.com zong@ukr.net, lusj0951@gmail.com

\begin{abstract}
Zon, I., Zon, G., \& Ivanovskaya, L. (2020). Clinical signs in dogs attributed to Yersinia enterocolitica antigen 0:9. Scientific Messenger of Lviv National University of Veterinary Medicine and Biotechnologies. Series: Veterinary sciences, 22(99), 161-166. doi: 10.32718/nvlvet9924

Canine yersiniosis is currently a scantily researched disease. Two agents predominately cause yersiniosis: Y. enterocolitica (gut yersiniosis), Y. preudotuberculosis (yersiniosis). There are three clinical forms of the disease: intestinal, generalized and secondary-focal. Current available research states the prevalence of $Y$. enterocolitica against other biovariants in canine infections. The majority of infected dogs demonstrate both asymptomatic clinical course and unspecific symptoms or serve as a carrier. Meanwhile yersiniosis pose a threat to human health causing a severe complex of symptoms. In some cases the disease can be lethal, thus the disease has both epizootological and epidemiological value. The goal of this paper was to generalize clinical signs in dogs that demonstrated positive reaction to Y. enterocolitica antigen 0:9, which is a dominant causative agent of yersiniosis in the northeastern region of Ukraine. The study was conducted based on clinical data, biochemical and hematological laboratory studies. Contamination of canine subjects with $Y$. enterocolitica 0:9 was conducted using agglutination reaction using respective antigen. The research showed, that the dominant symptoms in canines, affected by Yersinia serovariant 0:9 were gastrointestinal lesions in $100 \%$ of the cases. The clinical signs included melena or bloody stool, general depression, anorexia, cachexia, more rarely - vomiting, tachypnea and breathing irregularities. The results of biochemical blood assays and $C B C$ were heterogeneous and cannot be used as a specific marker of Yersinia infection. The main method of confirmation for Yersinia infection would be a serological agglutination reaction, which can identify positive diagnostic titers in animal blood samples. Further research is planned to study mono- and concurrent course of Yersiniosis with different infectious diseases.
\end{abstract}

Key words: dogs, Yersiniosis, antigen Y. enterocolitica 0:9, clinical signs.

\section{Клінічні ознаки у собак, що позитивно реагують на антиген Yersinia enterocolitica 0:9}

І. Г. Зон, Г. А. Зон, Л. Б. Івановська

Сумський начіональний аграрний університет, м.Суми, Украӥна

Ієрсиніоз собак досі маловивчене захворювання. Найчастіше його викликають два збудники - Ү. епtегосодіtica (кишковий ієрсиніоз) i Y. pseudotuberculosis (ієрсиніоз). Виділяють три клінічні форми хвороби: кишкову, генералізовану, вторинно-вогнещеву. Відомі дослідження вказують на превалювання Y. еnterocolitica над іншими біоварами в інфекиійному процесі у собак. У більшості інфікованих собак захворювання перебігає безсимптомно з неспецифічною клінічною картиною або у вигляді бактеріоносійства. Водночас ієрсиніози становляють загрозу здоров'ю людини, проявляючись складним симптомокомплексом, а в окремих випадках закінчуються летально. Тому ієрсиніоз має як епізоотологічне, так і епідеміологічне значення. Мета роботи - узагальнити клінічні ознаки у собак, які в діагностичних титрах реагували на ієрсиніозний антиген Y. епtеrосоіitica 0:9, домінуючий збудник кишкового ієрсиніозу собак в північно-східному регіоні України. У роботі використовували клінічні, гематологічні та біохімічні дослідження. Позитивні реакиії на контамінацію організму собак Y. епtеrocolitica 0:9 визначали в реакиії аглютинації 3 відповідним антигеном. Дослідження показали, щєо домінуючими симптомами при ураженні собак сероваром 0:9 у 100 \% випадків було ураження шилнково-кишкового тракту з діареєю, з домішками крові у фекаліях, на тлі пригнічення, анорексії, кахексії. Рідше хвороба супроводжувалася блюванням і порушенням ритму дихання. Результати гематологічних та біохімічних досліджень у 
собак з позитивною реакиією на іерсініозной антиген 0:9 характеризувалися різноманітністю і не можуть служсти діагностичним маркером ієрсиниозної інфекції. Основною підозрою на захворювання кишковим ієрсинізом може слугувати серологічна реакція аглютинації з виявленням позитивно реагуючих тварин в діагностичних титрах. Подальші дослідження планується спрямувати на вивчення моно- і асоційованого перебігу ієрсиніозу з іншими захворюваннями собак інфекційної природи.

Ключові слова: собаки, ієрсиніоз, антиген Y. епterocolitica 0:9, клінічні ознаки.

Вступ

Ієрсиніоз собак найчастіше спричиняється двома бактеріальними збудниками: Yersinia enterocolitica i Yersinia pseudotuberculosis. Найбільше поширення має так званий кишковий ієрсиніоз, що спричиняється Y.enterocolitica i $є$ особливо небезпечним для цуценят (Skibitskiy \& Kozlovska, 2012). В окремих повідомленнях описуються факти контамінації собак Y. intermedia та Y. frederiksenii (Fukushima et al., 1984). При кишковому ієрсиніозі інкубаційний період становить 1-6, іноді до 9 діб.

Смертність собак від кишкового ієрсиніозу може коливатися в межах 1-5\%. Частіше у тварин реєструють безсимптомний перебіг хвороби, який виявляють на фоні ускладнень іншими захворюваннями (Babkin \& Nikolaenko, 2005).

Експериментально доведено, що в організмі собак Y. enterocolitica може перебувати протягом 23 діб за відсутності симптомів (Fenwich et al., 1994; Hayashidani et al., 1995).

Інфіковані собаки можуть бути небезпечними для людей, особливо з низьким рівнем імунітету (Andreotti et al., 2007; Latiful et al., 2011; Bancerz-Kisiel \& Szweda, 2015), а також спричиняти забруднення довкілля при їх вигулі (Platt-Samoraj et al., 2000; Hetem et al., 2013). Про небезпечність захворювання для людини свідчить той факт, що в Німеччині (Rosher, 2010) і ЄС загалом ієрсиніози посідають третє місце після кампілобактеріозу і сальмонельозу (Polischuk, 2008; Drobyaschenko et al., 2010; Ushkalov, 2013).

Для виникнення хвороби має значення вірулентність збудника, вгодованість і вік тварини, наявність сприятливих факторів, а саме порушення в режимі й годівлі, якості кормів і утримання, наявності інших інфекційних та інвазійних хвороб (Babkin \& Nikolaenko, 2005). Зазвичай ієрсинії, що потрапляють в шлунок, гинуть за рахунок кислого середовища ( $\mathrm{pH} 2,5-$ $4,0)$, але за надвисокої концентрації збудника та зниження рівня імунітету тварини, активної перистальтики, бактерії здатні потрапити далі в кишечник, де відбувається колонізація його епітелію. На фоні катарального запалення Y.enterocolitica здатна потрапити у кров (Zon et al., 2013; 2017) і гематогенним шляхом заноситися в різні органи (печінку, нирки, легені тощо) (Murphy et al., 2010; Byun et al., 2011; Wang et al., 2011).

Збудник, уражаючи шлунково-кишковий тракт, спричиняє гастроентерит, діарею, кахексію у цуценят, а в дорослих тварин хвороба перебігає переважно безсимптомно. До основних симптомів зараховують: втрату апетиту, а згодом і відмову від споживання корму, гіпертермію, сонливість, кволість, анемію, іноді жовтяницю, блювання, пронос 3 домішками крові у фекаліях (Farsfad et al., 1976; Fukushima et al., 1984; Stamm et al., 2013).

Хвороба може перебігати в трьох формах: кишковій (гастроентерити); генералізованій (гепатити, ураження біліарної системи, нефрити, бронхопневмонія, сепсис); вторинно-вогнищевій (артрити, хронічні ентероколіти та ін.), що виникає внаслідок двох перших форм (Orehova, 2015).

В одних із перших повідомлень була інформація про інфікування собак Y. enterocolitica, яке може становити до 6 \% і навіть більше. Дослідженнями Fukuchima H. et al. (1984) встановлено, що серед обстежених 252 собак 27 були позитивними до ієрсиніозних антигенів, в тому числі до різних сероварів Y. enterocolitica (19,8\%), Yersinia pseudotuberculosis $6,3 \%, Y$. intermedia $-2 \%$ та $Y$. frederiksenii - 0,8\%. Ізоляція збудника часто відбувалася за хронічного ентериту (Farstad et al., 1976).

В повідомленнях з різних куточків світу надходить інформація про перевагу Y.enterocolitica над іншими біоварами в інфекційному процесі за ієрсиніозної інфекції, а також про різноманітне поширення певних сероварів збудника в різних регіонах. Так, в Свропі найбільш поширеними сероварами є 0:3 та 0:9, іноді 0:8; в США - 0:8; в Канаді та Японії - 0:5 і 0:7; в Китаї - 0:3 (Fenwich et al., 1994; Hayashidani et al., 1995). Нашими дослідженнями доведено, що в Україні у собак найпоширенішим сероваром Y. enterocolitica $€$ 0:9 (Zon et al., 2013; 2017), і набагато рідше виявляються серовари 0:6.30 та 0:3 (V'yalih et al., 2009).

Про актуальність досліджень щодо ієрсиніозу собак в Україні повідомляли (Ivanovskaya \& Zon, 1999; Zon et al., 2013, Orehova, 2015; Zon et al., 2017). Проте до цього часу такі дослідження мають фрагментарний характер і обмежено висвітлюють ті чи інші сторони проблеми.

3'вязок з державними науковими програмами. Дослідження є фрагментом НДР кафедри вірусології, патанатомії та хвороб птиці Сумського НАУ "Удосконалення методів ранньої діагностики і лікувальнопрофілактичних заходів для запобігання емерджентних та економічно значущих хвороб тварин” (№ державної реєстрації 0118U100371).

Метою роботи було узагальнення клінічних ознак у собак, які в діагностичних титрах реагували на ієрсиніозний антиген Y. enterocolitica 0:9. Для вирішення мети були поставлені такі завдання: дослідити сироватки крові собак в РА на серопозитивність до антигену Y. enterocolitica 0:9; провести диференціальну діагностику парвірусного ентериту; визначити клінічні показники та біохімічний статус позитивно реагуючих собак порівняно зі здоровими тваринами. 


\section{Матеріал і методи досліджень}

Дослідження проводили на кафедрі вірусології, патантомії та хвороб птиці Сумського НАУ та в клініці ветеринарної медицини "Ветсервіс" м. Суми, яка $\epsilon$ філіалом кафедри. В дослідженні використані дані від 7 собак, різних за породою і статтю, віком до 1,5 року, які були позитивні при дослідженні на ієрсиніозний антиген Y. enterocolitica $0: 9$.

Клінічний стан тварин оцінювали на підставі безпосереднього огляду та за анамнестичними даними, отриманими від хазяїв собак та лікарів клініки. Серологічні дослідження (РА) проводили шляхом використання сироваток, отриманих від піддослідних тварин, та антигену $Y$. enterocolitica $0: 9$ з "Набору компонентів для серологічної діагностики ієрсиніозів тварин”, виготовленого ННЦ “ІЕКВМ” (м. Харків). Кров для отримання сироватки у дослідних тварин відбирали 3 центральної вени передпліччя 3 дотриманням асептики і антисептики.
3 метою диференційної діагностики від парвовірусного ентериту проводили дослідження з використанням "Набору антигенів Sens PERT ${ }^{\circledR}$ Canine Parvovirus" (Vet ALL, Korea). Біохімічні дослідження проводили на аналізаторі Spectrumlab 23A, Model №23.407145 (China). Гематологічні показники отримували на аналізаторі Beckman Coulter, Coulter dif. Ac. T. (USA).

\section{Результати та їх обговорення}

Основна підозра на наявність ієрсиніозної інфекції у собак різних порід віком до 1,5 року виникала за наявності стійкого проносу з фекаліями, які містили кров.

Діагностичні дослідження 3 використанням тестів "Набору антигенів Sens PERT ${ }^{\circledR}$ Canine Parvovirus" (Vet ALL, Korea) в усіх випадках були негативними.

Позитивність до антигену Y. enterocolitica 0:9 ceред 7 собак показано в таблиці 1 .

\section{Таблиця 1}

Результати серологічних досліджень сироваток крові собак

\begin{tabular}{|c|c|c|c|c|c|c|c|}
\hline \multirow{2}{*}{$\begin{array}{c}\text { Антиген } \\
\text { Y. enterocolitica 0:9 }\end{array}$} & \multicolumn{7}{|c|}{ Клички собак } \\
\hline & $\begin{array}{c}\text { Берта } \\
\varnothing\end{array}$ & $\begin{array}{c}\text { Вайт } \\
\hat{0}\end{array}$ & $\begin{array}{c}\text { Tom } \\
\hat{0}\end{array}$ & 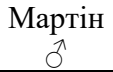 & \begin{tabular}{c} 
Лило \\
\multirow{\lambda}{\lambda}{}
\end{tabular} & $\begin{array}{c}\text { Hopa } \\
q\end{array}$ & $\begin{array}{c}\text { Лапа } \\
\overline{0}\end{array}$ \\
\hline Титри (кінцеве розведення в РА) & $1: 400$ & $1: 200$ & $1: 200$ & $1: 800$ & $1: 200$ & $1: 400$ & $1: 400$ \\
\hline
\end{tabular}

На підставі попередніх досліджень нами було встановлено, що розведення 1:200 можна вважати діагностичним титром і визначати тварину як хвору на кишковий ієрсиніоз.

Шляхом обстеження тварин і збору анамнезу були встановлені такі клінічні ознаки, наведені в таблиці 2.

Аналізуючи матеріали таблиці, можна констатувати, що домінуючим симптомом був пронос з вмістом

\section{Таблиця 2}

Клінічні ознаки у собак, що позитивно реагували на ієрсиніозний антиген Y. enterocolitica 0:9

\begin{tabular}{|c|c|c|c|c|c|c|c|c|}
\hline \multirow{2}{*}{$\begin{array}{c}\text { Реакція } \\
\text { систем та органів }\end{array}$} & \multirow{2}{*}{$\begin{array}{c}\text { Симптоми / } \\
\text { патології }\end{array}$} & \multicolumn{7}{|c|}{ Клички собак } \\
\hline & & Берта & Вайт & ToM & Мартін & Лило & Hopa & Лапа \\
\hline Загальні & Пригнічення & + & - & + & - & + & + & - \\
\hline \multirow[t]{4}{*}{ симптоми } & Анорексія & + & + & - & + & - & - & + \\
\hline & Блювання & - & + & - & - & + & - & + \\
\hline & Кахексія & + & + & - & + & - & + & - \\
\hline & Лихоманка & - & + & - & - & - & + & - \\
\hline Нервової системи & Тенезми & + & - & + & - & - & - & - \\
\hline ШКТ & Пронос & + & + & + & + & + & + & + \\
\hline \multirow[t]{2}{*}{ Респіраторної системи } & Порушення ритму дихання & - & + & - & + & - & - & + \\
\hline & Бронхопневмонія & - & - & - & - & - & - & + \\
\hline \multirow[t]{2}{*}{ Системи сечовиділення } & Нефрит & - & - & - & + & - & - & - \\
\hline & Нефроз & - & + & + & - & - & + & - \\
\hline \multirow[t]{3}{*}{ Статевої системи } & Ендометрит & - & - & - & - & - & + & - \\
\hline & Мастит & - & - & - & - & - & + & - \\
\hline & Орхіт & - & - & - & + & - & - & - \\
\hline \multirow[t]{2}{*}{ Лімфатичної системи } & Лімфаденіт & - & - & + & - & - & + & - \\
\hline & Тонзиліт & - & - & + & - & - & - & - \\
\hline Суглоби & Артрит /артроз & - & + & - & - & - & - & - \\
\hline Вуха & Отит & + & - & - & - & - & - & - \\
\hline \multirow[t]{2}{*}{ Шкіра } & Дерматит & - & - & - & - & - & - & + \\
\hline & Висипи & - & - & - & + & - & - & + \\
\hline
\end{tabular}


Результати біохімічних досліджень сироваток крові дослідних собак подані в таблиці 3.

Оцінюючи рівень активності ензимів у хворих собак, встановлено, що активність АлАТ та АсАТ тільки в двох випадках була вищою за норму і, ймовірно, пов'язана з ураженням печінки.

Щодо ЛФ - спостерігали підвищення активності в 5 випадках з 7, і це свідчить про ураження більшості паренхіматозних органів (печінка, нирки, підшлунко- ва залоза та ін.) на клітинному рівні. Водночас показники білірубіну (загального та прямого) залишалися в межах норми.

В чотирьох випадках констатували зниження рівня загального протеїну. Лише в одному випадку виявили зростання рівня сечовини (12,97 ммоль/л) проти максимального рівня в нормі - 8,93 ммоль/л. Рівень глюкози, Кальцію, Калію, Натрію і Хлору в більшості тварин залишався в межах норми.

Таблиця 3

Біохімічні показники сироваток крові собак, позитивно реагуючих на ієрсиніозний антиген Y. enterocolitica 0:9

\begin{tabular}{|c|c|c|c|c|c|c|c|c|c|c|}
\hline \multirow{2}{*}{$\begin{array}{l}\text { № } \\
\text { 3/ח } \\
\end{array}$} & \multirow{2}{*}{ Показники } & \multirow{2}{*}{$\begin{array}{c}\text { Одиниці } \\
\text { виміру }\end{array}$} & \multirow{2}{*}{$\begin{array}{c}\text { Показники } \\
\text { норми }\end{array}$} & \multicolumn{7}{|c|}{ Клички собак } \\
\hline & & & & Берта & Вайт & Том & Мартін & Лило & Hора & Лапа \\
\hline 1 & АлАТ & $\mathrm{MO} / л$ & $8,2-70,0$ & 10 & 69,2 & 82 & 100,2 & 44 & 23,6 & 77,4 \\
\hline 2 & AcAT & MO/л & $8,9-43,0$ & 44 & 35,7 & 39 & 56,2 & 70 & 23,4 & 25,0 \\
\hline 3 & ЛФ & МО/л & $10-60$ & 152 & 55 & 84 & 96,7 & 87 & 13,3 & 95,7 \\
\hline 4 & Білірубін загальний & ммоль/л & $0,9-10,6$ & 10,3 & 3,7 & 7,8 & 9,0 & 5,5 & 4,9 & 7,7 \\
\hline 5 & Білірубін прямий & ммоль/л & $0-10$ & 1,2 & 0,7 & 0,8 & 2,5 & 0,6 & 1,0 & 2,5 \\
\hline 6 & Протеїн загальний & г/л & $55,1-75,2$ & 42 & 49,1 & 66 & 55,8 & 51 & 60,9 & 54,2 \\
\hline 7 & Сечовина & ммоль/л & $2,86-8,93$ & 4,25 & 4,8 & 7,1 & 6,8 & 3,52 & 2,5 & 12,97 \\
\hline 8 & Глюкоза & г/л & $3,4-6,0$ & 5,21 & 5,1 & 4,84 & 7,4 & 5,27 & 4,3 & 5,78 \\
\hline 9 & Кальцій & ммоль/л & $2-2,7$ & 2,47 & 2,4 & 2,42 & 2,3 & 2,16 & 2,4 & 1,79 \\
\hline 10 & Калій & ммоль/л & $3,5-5,7$ & 4,03 & 4,7 & 4,44 & 4,8 & 3,86 & 4,8 & 5,8 \\
\hline 11 & Натрій & ммоль/л & $141-155$ & 139 & 146 & 143 & 146 & 137 & 146 & 94 \\
\hline 12 & Хлор & ммоль/л & $103-115$ & 106 & 114 & 111 & 110 & 104 & 109 & 57 \\
\hline
\end{tabular}

Примітка: АсАТ - аспартатамінотрансфераза; АлАТ - аланінамінотрансфераза; ЛФ - лужна фосфатаза

Результати гематологічних досліджень крові собак подані в таблиці 4, 3 якої видно, що концентрація гемоглобіну в двох випадках дещо перевищувала максимальний показник, але водночас у однієї тварини встановили різке зниження цього показника до 55 г/л (проти мінімального рівня 120 г/л). Останнє може бути наслідком певної супутньої патології.

Майже у половини тварин рівень гематокриту був нижчим за нормативний, в одному з випадків навіть удвічі (16,5 \% проти 37 \%). Рівень еритроцитів у трьох тварин дещо зростав (можливо, за рахунок компенсаторної регенерації) і лише в одному випадку був удвічі меншим проти мінімального показника. Водночас в показниках середнього об'єму еритроцитів та середньої концентрації гемоглобіну в еритроциті суттєвих зсувів не виявлено.

У більшості тварин загальна кількість лейкоцитів була в фізіологічних межах, і тільки в однієї тварини констатували різке зменшення показника до 2,92 Г/л, що може бути пов'язано з іншим негативним впливом на організм собаки.

Рівень лімфоцитів в більшості випадків був у межах норми, проте в однієї тварини він зріс до $43 \%$, а в іншої констатовано різке падіння показника до 1,0%.

\section{Таблиця 4}

Гематологічні показники крові собак, позитивно реагуючих з ієрсиніозним антигеном Y. enterocolitica 0:9

\begin{tabular}{|c|c|c|c|c|c|c|c|c|c|}
\hline \multirow{2}{*}{ Показники } & \multirow{2}{*}{$\begin{array}{c}\text { Одиницы } \\
\text { виміру }\end{array}$} & \multirow{2}{*}{ Норма } & \multicolumn{7}{|c|}{ Клички собак } \\
\hline & & & Берта & Вайт & Том & Мартін & Лило & Нора & Лапа \\
\hline Гематокрит & $\%$ & $37-55$ & 16,5 & 46,5 & 51,0 & 38,5 & 50,1 & 30,6 & 31,1 \\
\hline Гемоглобін & г/л & $120-180$ & 55 & 175 & 197 & 146 & 185 & 200 & 133 \\
\hline Еритроцити & Т/л & $5,5-6,5$ & 2,64 & 7,58 & 8,0 & 6,54 & 7,59 & 8,61 & 5,75 \\
\hline Середній об’єм еритроцитів & мкм ${ }^{3}$ & $60-75$ & 61,5 & 61,3 & 63,8 & 58,9 & 66 & 98,8 & 54,1 \\
\hline $\begin{array}{l}\text { Середній вміст гемоглобіну } \\
\text { в еритроциті }\end{array}$ & Пг & $20-25$ & 20,8 & 23,1 & 24,6 & 22,3 & 24,2 & 23,2 & 23,1 \\
\hline $\begin{array}{l}\text { Середня концентрація гемо- } \\
\text { глобіну в еритроциті }\end{array}$ & г/л & $330-380$ & 333 & 371 & 386 & 379 & 367 & 395 & 428 \\
\hline Лейкоцити & Г/л & $6-17$ & 2,92 & 16,72 & 8,42 & 13,6 & 11,88 & 9,97 & 12,84 \\
\hline Лімфоцити & $\%$ & $12-30$ & 18 & 16 & 21 & 43 & 21 & 20 & 1 \\
\hline $\begin{array}{l}\text { Нейтрофіли: } \\
\text { - сегментоядерні }\end{array}$ & $\%$ & $60-70$ & 42 & 44 & 60 & 38 & 59 & 61 & 82 \\
\hline - паличкоядерні & $\%$ & $2-6$ & 9 & 5 & 4 & 8 & 4 & 5 & 11 \\
\hline Моноцити & $\%$ & $2-7$ & 36 & 6 & 12 & 10 & 12 & 3 & 2 \\
\hline Еозинофіли & $\%$ & $2-5$ & - & 29 & 3 & - & 4 & 11 & 4 \\
\hline Базофіли & $\%$ & рідко & - & - & - & - & - & - & - \\
\hline Тромбоцити & Г/л & $200-500$ & 400 & 305 & 226 & 483 & 399 & 260 & 182 \\
\hline
\end{tabular}


Якщо у трьох тварин рівень сегментоядерних нейтрофілів був нижчим за норму, а в однієї тварини дещо зріс (до 8,2 Т/л), то рівень паличкоядерних нейтрофілів збільшився тільки у двох випадках з 7. Водночас більше як у половини досліджених встановлювали моноцитоз.

В двох випадках констатували еозинопенію, а у двох інших собак, навпаки - еозинофілію. Рівень тромбоцитів в усіх тварин був у межах норми.

\section{Висновки}

1. Підозра в інфікуванні собак Y.enterocolitica підтверджується позитивними реакціями сироваток тварин $з$ відповідними антигенами в РА в діагностичних титрах.

2. Домінуючими клінічними ознаками за кишкового ієрсиніозу, спричиненого $Y$. enterocolitica серовара 0:9, є 100 \% ураження кишечника, що супроводжується кривавою діареєю на фоні пригнічення, анорексії, кахексії, рідше блювання та порушення ритму дихання.

3. Біохімічні і гематологічні показники у собак, позитивно реагуючих на ієрсиніозний антиген $Y$. enterocolitica $0: 9$, характеризуються різноманітністю і не можуть слугувати діагностичними маркерами ієрсиніозної інфекції, а лише орієнтувати на симптоматичну терапію.

\section{References}

Andreotti, O., Budka, H., Buncic, S. ... Vanopdenbosch, E. (2007). Monitoring and identification of human enteropathogenic Yersinia spp. Scientific Opinion of the Panel on Biological Hazard. The EFSA Journal., 595, 1 - 30. doi: 10.2903/j.efsa.2007.595.

Babkin, A. F., \& Nikolaenko, M. N. (2005). Serologicheskie issledovaniya sluzhebnyih sobak na brutsellez, iersinioz i hlamidioz $\mathrm{v}$ pitomnikah $\mathrm{s}$ uchetom kliniko-epizootologicheskih danih [Serological studies of service dogs for brucellosis, yersiniosis and chlamydia in kennels, taking into account clinical and epizootological data]. Veterinarna meditsina: mIzhvIdomchiy tematichniy naukoviy zbIrnik , HarkIv: "NNTs" IEKVM, 1, 72-76 (in Russian).

Bancerz-Kisiel, A., \& Szweda, W. (2015). Yersiniosis zoonotic foodborne disease of relevance to public health Ann. Agric. Environ Med., 22(3), 397-402. doi: 10.5604/12321966.1167700.

Byun, J. W., Yoon, S. S., Lum, S. K., Lu, O. S., \& Jung, B. Y. (2011). Hepatic Yersiniosis caused by Yersinia enterocolitica 4:03 in an adult dog. J. Vet. Diagn. Invest., 23(2), 376-378. doi: 10.1177/104063871102300233.

Drobyaschenko, M. A., Pushkareva, V. I., Yurov, D. S., \& Polyakov, V. Yu. (2010). Kolonizatsiya i razmnozhenie Yersinia enterocolitica $09 \mathrm{v}$ pischevyih produktah, izgotovlenyih v sovremennyih tehnologicheskih usloviyah. [Colonization and propagation of Yersinia enterocolitica 09 in food products manufactured under modern technological conditions]. Epidemiologiya i vaktsinoprofilaktika, 4, 51-57 (in Russian).

Farsfad, L., Landsverk, T., \& Lasser, J. (1976). Isolation of Yersinia enterocolitica from a dog with chronic enteritis: a case report. Acta vet. Scand., 17(2), 261263. URL: https://pubmed.ncbi.nlm.nih.gov/952255.

Fenwich, S. G., Madie, P., \& Wilks, C. R. (1994). Duration of carriage and transmission of $\mathrm{Y}$. enterocolitica biotype 4, serotype 0:3 in dogs. Epidemiology and Infection, 113(3), 471-477. doi: $10.1017 \% 2 F s 0950268800068485$.

Fukushima, H., Nakamura, R., Iitsuka, S., Tsubokura. M., Otsuki, K., \& Kawaoka, Y. (1984). Prospective Systematic study of Yersinia spp. in Dogs. J. of Clinical Microbiol, 19(5), 616-692. URL: https://www.ncbi.nlm.nih.gov/pmc/articles/PMC2711 42.

Hayashidani, H., Kaneko, K., Sakurai, K. \& Ogawa, M. (1995). Experimental infection with Y. enterocolitica serovar 0:8 in Beagle dogs. Vet. Microbiol, 47(1-2), 71-72. doi: 10.1016/0378-1135(95)00052-C.

Hetem, D. J., Pekelharing, M., \& Thijsen, S. F. T. (2013). Probable transmission of Yersinie enterocolitica from a pet dog with diarrhea to 1-year-old infant. BMC Journal, 2013, bcr2013200046. doi: 10.1136/bcr2013-200046.

Ivanovskaya, L. B., \& Zon, M. G. (1999). K izucheniyu roli $\mathrm{Y}$. enterocolitica $\mathrm{v}$ patologii plotoyadnyih. [To study the role of $\mathrm{Y}$. enterocolitica in the pathology of carnivores]. Mater.VII Mezhd. konf. na probl. vet. med. melk. dom. zhivotnyih (3-5 marta 1999 g.). M., 262-263 (in Russian).

Latiful, B., Hossain, M. A., Isshiki, K., \& Ukuku, D. (2011). Behavior of Yersinia enterocolitica in Foods. Journal of Pathogens, 2011, 420732. doi: 10.4061/2011/420732.

Murphy, B. P., Drummond, N., \& Ringwood, T., et al. (2010). First report: Yersinia enterocolitica recovered from canine tonsils. Veter. Microbiology, 146(3-4), 336-339. doi: 10.1016/j.vetmic.2010.05.033.

Orehova, G. A. (2015). Kishkoviy iersinioz tvarin (aktualnIst, epIzootologIya, dIagnostika). [Intestinal yersiniosis of animals (relevance, epizootology, diagnosis). NNTs "IEKVM", N. sb. "Veterinarna meditsina", 101, 125-129 (in Ukrainian).

Platt-Samoraj, A., Szweda, W., \& Siwicki, A. K. (2000). Wplyw zakazen Y.enterocolitica psow i kotow na wystepowanie jersiniozy u czlowieka. Med. veter., 56(6), 379-381. URL: http://www.medycynawet.edu.pl/ images/stories/pdf/digital/2000/200006379382.pdf.

Polischuk, N. M. (2008). Epidemiologichni ta epizootologichni aspekti iersinioziv [Epidemiological and epizootological aspects of yersiniosis]. Annals of Michnicov institute, 4, 5-8 (in Ukrainian).

Rosher, B. M., Stark, K., \& Werber, D. (2010). Epidemiology of reported Yersinia enterocolitica infection in Germany, 2001-2008. BMC Public Health, 10, 337. doi: 10.1186/1471-2458-10-337. 
SkibItskiy, V. G., \& Kozlovska, G. V. (2012). Zbudnik kishkovogo IErsinIozu - Yersinia enterocolitica ta pov'yazanI z nim problem [The causative agent of intestinal yersiniosis is Yersinia enterocolitica and related problems]. GumanItarnI ta resursnI problemi natsionalnoyi bezpeki Ukrayini. Kyiv, kn.2, 19-31 (in Ukrainian).

Stamm, I., Hailer, M., Depner, B., Kopp, P. A., \& Rau, J. (2013). Yersinia enterocolitica in Diagnostic Fecal Samples from European Dogs and Cats: Identification by Fourier Transform Infrared Spectroscopy and Matrix-Assisted Laser Desorption Ionization-Time of Flight Mass Spectrometry. J. clin microbio, 51(3), 887-893. doi: 10.1128/JCM.02506-12.

Ushkalov, A. V. (2013). EpIzootichna ta epIdemIologIchna harakteristika IErsinIozIv. Veterinarna meditsina UkraYini [Epizootic and epidemiological characteristics of yersiniosis. Veterinarna meditsina ukrayini, 11(213), 15-18 (in Ukrainian).

V'yalih, Zh. E., Yakovenko, T. B., Drobot, O. V., Sorochan, O. S., Gubar, O. V., \& Levitska, S. L. (2009). SerologIchna nalezhnIst shtamIv Yersinia enterocolitica, vidIlenih z rIznih ob'EktIv na teritorIYi
UkraYini [Serological affiliation of Yersinia enterocolitica strains isolated from different objects on the territory of Ukraine]. ProfIlaktichna meditsina, 4(8), 36-39 (in Ukrainian).

Wang, H., Cui, Y., Wang, Z., Wang, X., Guo, Z., Yan, Y., Li, C., Cui, B., Xiao, X., Yang, Y. et al. (2011). A dog - associated primary pneumonic plague in Qinghai Province, China. Clin. Infect. Dis., 52(2). 185-190. doi: $10.1093 / \mathrm{cid} / \mathrm{ciq} 107$.

Zon, G. A., Ivanovskaya, L. B., Kuznetsov, M. Yu., \& Kuznetsova, E. Yu. (2013). OtsInka rezultatIv seropozitivnostI sobak $\mathrm{z}$ iersinioznimi antigenami [Evaluation of the results of seropositivity of dogs with Yersinia antigens]. Mizhvid. tem. nauk. zb. "Veterinarna meditsina". Harkiv: NNTs "IEKVM", 97, 96-98 (in Ukrainian).

Zon, G. A., Kuznetsova, E. Yu., \& Ivanovskaya, L. B. (2017). Rezultati retrospektivnoYi serologIchnoYi dIagnostiki kishkovogo IErsinIozu sobak v SumskIy oblastI [The results of retrospective serological diagnosis of intestinal yersiniosis in dogs in Sumy region]. Zb. nauk. prats "Agrarniy vIsnik Prichornomor'ya", serIya "Veter. Nauki", Odesa, 83, 93-97 (in Ukrainian). 